Yuriy Yula,

Sumy State University, Ukraine

email:y.yula@kmm.sumdu.edu.ua

Olexandr Pushko,

Sumy State University, Ukraine

Maksym Palienko,

University of Insubria, Italy

Correspondence author: y.yula@kmm.sumdu.edu.ua

\title{
RECOMMENDATIONS FOR IMPROVING THE HOSPITAL'S MARKETING POLICY
}

Abstract. This article summarizes the arguments and counterarguments within the scientific discussion on improving the marketing policy of the clinic. The purpose of the study is to improve the marketing policy of the clinic. The urgency of solving the scientific problem lies in need to promote medical services, where marketing activities contribute to establishing relations between providers and consumers of medical services. The authors noted that patients have a low level of awareness in medical services, making it difficult to understand the market of medical services. In turn, public and municipal health care facilities have a passive marketing policy that is not competitive enough with private health care facilities. In most cases, state and municipal medical institutions do not use marketing tools to acquaint consumers with the list of available services, do not inform consumers about the expansion of medical services and the benefits of their medical institution. The object of the study was selected health care management. According to the results of empirical analysis of ways to improve the marketing policy of the clinic, it is established that the reform of the medical sector of Ukraine intensifies the processes of competition in the market. The marketing system of Ukrainian health care has no concept of medical care. Instead of that, there is a market element as medical service or health care service provided to the patient by a health care institution or an individual registered according to the law and possessing the medical business license. Besides, the medical services are paid for by the customer, such as patients, various organizations, local authorities, and the government. Thus, public medical institutions faced the need to fight (particularly with private medical institutions) for the consumer and state funding for the package of primary medical services. The study empirically confirms and theoretically proves the existence of competition between private and public medical institutions in the market of medical services. The results of this study can help improve the marketing policy of public and municipal clinics.

Keywords: marketing tools, marketing policy, healthcare, staff, pricing policy.

Introduction. Human life and health are considered to be the priority values of society. Thus, health care is one of the socially essential life spheres. It stands to mention that despite health care is strongly regulated by the government, the active development of market economy principles influenced the health care sector.

Notably, the current health care market involves the medical institutions providing free medical care for the population by state order and by medical institutions providing paid medical services to the population. Besides, intermediaries embodied in insurance companies have appeared in the health care sphere. It is worth noting that the most crucial task of all medical institutions is to fully meet the public needs in medical services to prevent and treat the disease.

In turn, the market structure split, the new entities emergence, and consumer orientation require the development of marketing activities in medical services. The health care market grows every year both due to the number of consumers and the regular establishment of new medical institutions, primarily private. Moreover, the accelerating R\&D in medicine contributes to improving the quality of medical

Cite as: Yula, Yu., Pushko, O., \& Palienko, M. (2020). Recommendations for Improving the Hospital's Marketing Policy. Health Economics and Management Review, 2, 91-99. http://doi.org/10.21272/hem.2020.2-10 
services and increasing their number. Therefore, the market is intensifying competition and struggle for each customer. It is believed that marketing mechanisms will help medical institutions to manage the consumers' behaviour of medical services, increase interest in medical institutions and build trust in them.

Literature Review. The systematization of scientific treatise indicated the worldwide interest in investigating issues of marketing activities in medical services by researchers such as O. Aristov, M. Artyukhin, L. Zatsna, T. Ivashkiv, O. Kalinichenko, N. Petrova, A. Serzhuk, Sokolova Y., Pasichnyk K., Melnichenko O. and others.

The researcher Artyukhina M. considered the segmentation of medical services customers and analyzed the main elements of the marketing complex of medical institutions. On the other hand, Kalinichenko $O$. identified the characteristics of the medical service necessary in developing marketing programs. The researchers Zatsna L. and Ivashkiv I. presented the concepts of «medical service» and «health care market». In the study, the scientists evaluated the marketing orientation of medical institutions and characterized the domestic health care market.

In turn, Serzhuk A. reveals the concept of «medical service» in terms of marketing. In the study, the author analyzed the marketing complex components in the healthcare market to substantiate their importance in ensuring the effective functioning of the medical institution.

It stands to mention the study Sokolova and Pasichnyk (2019) considered the marketing tools in state medical institutions for strengthening their competitiveness under conditions of growing competition on the medical services market, reducing the quality of public medicine, and reorientating consumers to the private sector. The authors revealed the essence of «healthcare marketing» and its features compared to the physical product. Besides, there were shown the main directions in medical services that could be used by hospitals while elaborating marketing programs.

In the paper Melnychenko (2018), the author stated that the public health and life expectancy state significantly depends not only on hereditary background and lifestyle but also on access to quality medical services. The researcher emphasized the complexity of medical reform, the pattern of the domestic health care system and the tendency in population transiting (for the most part) from free medical services to pay.

Kalinichaenko (2016) studied health marketing as a separate line of marketing services. Thus, health marketing is considered an entrepreneurial activity, promoting services from its manufacturer (medical worker) to the consumer (patient). The author stated that the main subjects of the marketing system of medical services interact with each other through a medical institution.

Several scientists (Laburceva, 2017; Levina, 2016) concluded that the main marketing relationship essence between the medical worker and the patient is not providing and receiving medical services but meeting the target needs of each other.

Methodology and research methods. The health care market by economic activity includes health care market; pharmaceutical market; market of medical equipment and technologies; medical R\&D market; medical insurance market; medical education market; and medical tourism market (Table 1). It stands to note that each type mentioned above of market perform its functions in the health care system at different levels (national, regional, global). As individual consumers of medical goods and services, medical institutions and companies, insurance market participants, and the government create demand on this market. Under this classification, some participants are subjects of supply in certain market segments and the subjects of demand in others (Vezha, 2020).

By geographical feature, private medical services are provided at national, regional and global levels. In turn, the market of public health care covers national and regional scale. 
Table 1. The structure of the health care market

\begin{tabular}{ll}
\hline \multicolumn{1}{c}{ Criterion } & Types of markets \\
\hline By economic activity & $\begin{array}{l}\text { pharmaceutical market } \\
\text { the market of medical equipment and technologies } \\
\text { medical R\&D market } \\
\text { medical insurance market } \\
\text { medical education market } \\
\text { medical tourism market }\end{array}$ \\
\hline By competitiveness & Competitive market \\
& non-competitive market \\
\hline By ownership of the means of & government health care market \\
production & private health care market (commercial and noncommercial) \\
\hline By geography feature & national market \\
& regional market \\
global market
\end{tabular}

Sources: developed by the authors based on (Zatsna and Ivashkiv, 2017).

It is worth noting that it operates under market conditions despite the non-market nature of the public health sector. Thus, manufacturers of public health services enter into commodity-money relations with the subjects of other local health care markets viz the production factors market and insurance services market. Moreover, health care providers enter into commodity-money relations with other institutional market units outside the health care system.

Notably, the main factor in the competition between public and private medical services is the medical and preventive and socio-economic quality of medical services. In turn, the monopolistic essence of the non-competitive health care market is integrating management processes and industry financing. The state serves as both a seller and a buyer of medical services. However, in the permanent non-competitive conditions, that leads to a decrease in the quality of health care and inefficient use of financial resources (Yanchak, 2017).

The market actors are prominent in the health care market. They perform regulatory and control functions at various levels: government and health management, law enforcement and judicial systems, consumer protection associations, self-regulatory medical organizations, associations of medical 
insurance organizations and others (Table 2). However, the health care market is alien from the other markets. Thus, the main distinctive features of the health care market are as follows (Shomnikova, 2009):

- the subject of market activity is a person and health; the health care activity involves a high percentage of the intellectual component;

- a certain personification in providing medical care causes a need for personal contacts of producers and consumers of medical services; the interaction between doctor and patient is nonstandard and individual;

- the health care market demonstrates an information asymmetry of producers and consumers of medical services regarding the consumer appeal of medical services; the lack of information and specific insensitivity of medical services complicates the process of their consumption.

Table 2. The structure of the health care market

\begin{tabular}{ll}
\hline \multicolumn{1}{c}{ Market of other services } & \multicolumn{1}{c}{ Health care market } \\
\hline Many sellers & $\begin{array}{l}\text { The number of sellers is limited; limited entry into the } \\
\text { market; possible nature monopoly }\end{array}$ \\
\hline Seller estimates the volume and service types & Buyer influences the service proposition \\
\hline Homogeneous products & Inhomogeneity in medical service, its features \\
\hline Good informatization of consumers & Imperfect information \\
\hline Possibility to get in reserve & Inability to save \\
\hline Source nonseparability & Source and receiver nonseparability \\
\hline Price as the main factor & $\begin{array}{l}\text { Price is one of many factors (such as quality, terms, } \\
\text { production methods, etc.) }\end{array}$ \\
\hline Possibility to compare services price and quality & $\begin{array}{l}\text { Impossibility or difficulties in comparing services price and } \\
\text { quality }\end{array}$ \\
\hline Impersonal market mechanism concerning & $\begin{array}{l}\text { The market is customized; the customer gets into tight } \\
\text { relations with producer/intermediary (insurance company) }\end{array}$ \\
needs of many seller and buyer & Very sensitive to internal and external fluctuations \\
\hline Relatively change-insensitive in internal and & \\
\hline external policy & Demand is determined by proposed services or existing \\
income & estimation. Using the final publications could be an \\
& advantage \\
\hline Need in special services is respectively stable & Medical demand depends on the morbidity rate \\
\hline Producers try to maximize the profit & $\begin{array}{l}\text { Existing many state or private noncommercial } \\
\text { organizations }\end{array}$ \\
\hline
\end{tabular}

Sources: developed by the authors based on (Social communications research center, 2020; Medosvita, 2020).

The findings showed that, on the one hand, the information asymmetry in the health care market manifests as the fact that the patient cannot assess the doctor competence, the quality of medical equipment or drugs, and lack of access to information on these issues. On the other hand, the doctor has no access to the medical history on frequent occasions. Therefore, it causes complications in diagnosing illness and the need to repeat medical procedures.

Thus, it is worth mentioning that the national health market feature is combining private and public health services segments, each of which performs functions that can minimize the gaps of the other.

Results. The statistical data analysis showed that private clinics and diagnostic centres dominate the health care market in Ukraine (Fig. 1). In third place are dental services provided mainly by private practitioners in small offices. On the other hand, the reproductive medicine segment is maintained by foreign clients too. At last, the smallest market share is private oncology clinics, represented by three centres over the previous two years (Legan and Krykun, 2020). 


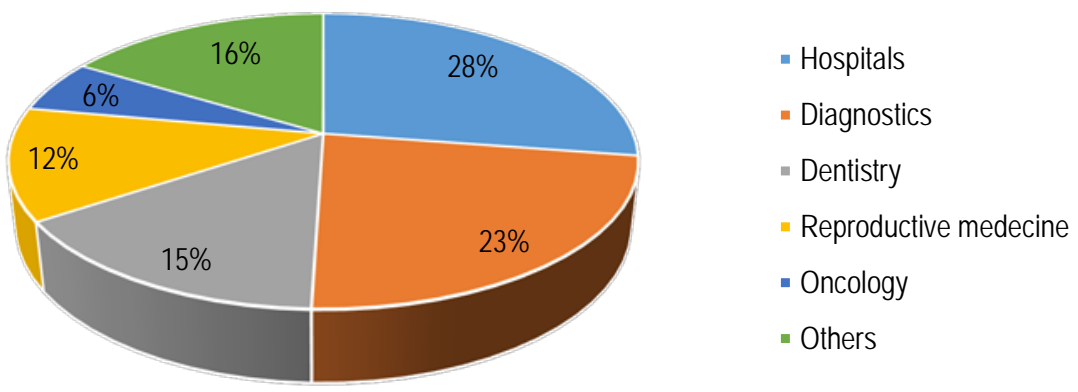

Figure 1. The structure of the private health care market in Ukraine Sources: developed by the authors based on (Chortorotov, 2010; Zukin, 2017).

The findings showed no significant rise in the number of private medical clinics in Ukraine from 2019 till the first half of 2020. Notably, the market value increased mainly due to attracting new customers and advance in service prices. Therefore, it is possible to conclude the strong dependence of the health care market development on the disposable income growth of the compatriots. It stands to emphasize that private medicine's main current growth points are large cities with the highest average wages. However, compulsory health insurance will be an additional catalyst to increase Ukraine's healthcare market capacity (Censor, 2020).

The current health care market is a segment of the world service market providing stable, systematic operations for the medical service exchange, including medical technology, medical devices, medical activities methods, pharmacological agents, drugs, prevention measures diseases, etc. Notably, the current health care market aimed at qualitative change of human health indicators. Therefore, it is standardized, regulated and regularized by special bodies and organizations at various levels.

This study involved Porter's five forces analysis in estimating the polyclinic competitiveness. The analysis was conducted using tables of competitiveness parameters, assigning each parameter a score that reflects the low, medium or high degree of threat to the polyclinic. Estimating the impact of each competitive force takes to choose one of three statements in the table. Then, it has to be put the appropriate score from 1 to 3 . At last, the scores are summed at the end of each table to give their value (Porter, 2015).

In turn, estimating the threat level takes to fill in 5 tables providing parameters for competition estimation, while a 3-point scale provides the parameter estimation. It is worth pointing out that Porter's competitive forces model describes thee parameters that must be considered analyzing the market competition. Table 3 demonstrates the threat level from substitute products (qualified doctors). Table 4 presents the rating of industry competition. Table 5 shows the threat of new competitors capable of market redistributing.

Table 3. Threat estimation by the substitute goods

\begin{tabular}{cccc}
\hline Estimated parameter & \multicolumn{3}{c}{ Estimation } \\
\hline $\begin{array}{c}\text { Substitute goods } \\
\text { «Price-quality» }\end{array}$ & $\begin{array}{c}\text { Exists and occupy substantial } \\
\text { market share }\end{array}$ & $\begin{array}{c}\text { Exists and have a } \\
\text { substantial market share }\end{array}$ & Unexist \\
\hline Overall score & 3 & & 2 \\
\hline
\end{tabular}


Continued Table 3

\begin{tabular}{cc}
\hline 1 point & Low threat from substitute goods \\
\hline 2 point & Average threat from substitute goods \\
\hline 3 point & High threat from substitute goods \\
\hline Sources: developed by the authors based on (Sokolova and
\end{tabular}

Table 4. Industry competition estimation

\begin{tabular}{|c|c|c|c|}
\hline Estimated parameter & \multicolumn{3}{|c|}{ Estimation } \\
\hline Number of employees & Large quantity & $\begin{array}{c}\text { Average quantity } \\
(5-7)\end{array}$ & Small quantity \\
\hline Market growth rate & Absent or negative & Low & High \\
\hline Limitation in price rising & $\begin{array}{c}\text { Intense price } \\
\text { competition on the } \\
\text { market. There are } \\
\text { no possibilities to } \\
\text { price rise }\end{array}$ & $\begin{array}{l}\text { There is a possibility } \\
\text { for price rise in the } \\
\text { frame of covering cost } \\
\text { outcome }\end{array}$ & $\begin{array}{l}\text { Permanent } \\
\text { possibilities for a price } \\
\text { rise to cover the cost } \\
\text { outcome and return } \\
\text { improving }\end{array}$ \\
\hline Overall score & & 6 & \\
\hline 1 point & \multicolumn{3}{|c|}{ Low intra-industry competition } \\
\hline 2 point & \multicolumn{3}{|c|}{ Average intra-industry competition } \\
\hline 3 point & \multicolumn{3}{|c|}{ High intra-industry competition } \\
\hline
\end{tabular}

Table 5. Threat estimation of new market competitors by entry barriers

\begin{tabular}{|c|c|c|c|}
\hline \multirow{2}{*}{ Estimated parameter } & \multicolumn{3}{|c|}{ Estimation } \\
\hline & 3 & 2 & 1 \\
\hline $\begin{array}{l}\text { Strong brands high standard of } \\
\text { knowledge and loyalty }\end{array}$ & Absent & $2-3$ & Above 3 \\
\hline Product differentiation & Low rate & Average rate & High rate \\
\hline Access to distribution channels & Fully opened & $\begin{array}{l}\text { Requires moderate } \\
\text { investing }\end{array}$ & Limited \\
\hline $\begin{array}{l}\text { Government policy (government } \\
\text { intervention level) }\end{array}$ & absent & Low rate & High rate \\
\hline Industry growth rate & $\begin{array}{c}\text { High and } \\
\text { accelerating }\end{array}$ & Slowed & Stagnation or decline \\
\hline Overall score & & 8 & \\
\hline 6 points & Low entrance lev & ew market players & \\
\hline 7-12 points & Average entranc & of new market players & \\
\hline 13-18 points & High entrance le & ew market players & \\
\hline
\end{tabular}

Sources: developed by the authors based on (Sokolova and Pasichnyk, 2019).

Figure 2 demonstrates the degree of competitive forces impact on the polyclinic. Therefore, it is clear that potential clients, consumers, and suppliers significantly impact polyclinic. 


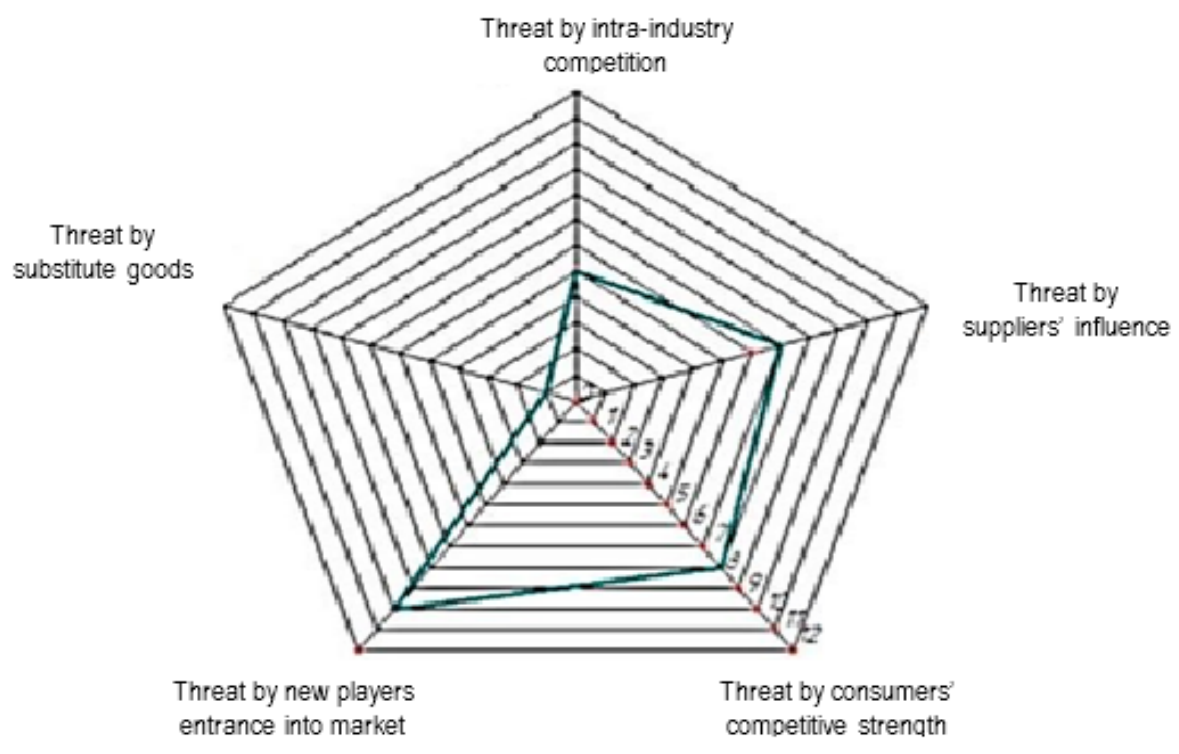

Figure 2. Influence of competitive forces

Sources: developed by the authors based on (Polienko, 2005; Popova, 2011; Porter, 2015; Sokolova and Pasichnyk, 2019).

The necessity to retain the existing VIP patients and attract new ones could be emphasized with obtained results. Moreover, it is essential to maintain specialists by offering better working conditions and implementing the best world practice. Therefore, the marketing tools should be both focused on consumer and medical staff.

Conclusions. The findings showed that the marketing system of Ukrainian health care has no concept of medical care. Instead of that, there is a market element as medical service or health care service provided to the patient by a health care institution or an individual registered according to the law and possessing the medical business license. Besides, the medical services are paid for by the customer, such as patient, various organizations, local authorities, and the government (Lehan et al., 2009; Foygt, 2011; Shynkaryova, 2007).

Systematization of scientific background showed that medical service is considered a product with consumer value due to its ability to meet the patients' needs for personal health. Besides, it should assure solving problems arising from ill-health. Therefore, the marketing of medical services aims to develop the population motivation to build a healthy and appropriate lifestyle, create a healthy person's image and healthy living system.

Following the mentioned above, the healthcare provider could take the following measures to build patient trust:

- increasing the product sensitivity;

- describing the service focusing on its benefits (such as time savings, quality diagnostics, guarantees, etc.);

- using the brand name to differentiate the services;

- providing promotional activities and others. 
It stands to note that the person (medical staff) providing the medical service is part of it. In turn, since the patient is always present during the health care delivery, the interaction between provider and patient is a particular aspect of medical services marketing. Therefore, to speed up the service delivery process and reach more patients, it is appropriate for the medical institution to:

- $\quad$ establish an accurate time for specific services delivery, including manipulating (biomaterial collection, laboratory tests, etc.);

- $\quad$ increase the number of professionals providing medical services.

On the other hand, the quality of medical services varies widely depending on their providers, time, the place for provision, and equipment.

It worth indicating that despite service quality is hard to control, it is possible due to measures as follows:

_ $\quad$ involving the high-quality specialists, training and medical staff development;

- continuously monitoring the patients' satisfaction while stimulating feedback to assess the patient loyalty to the medical institution;

- $\quad$ simplify certain stages of the medical service delivery process (automated registration for an appointment via an electronic form or the institution's website, receiving the results of laboratory tests online, various forms of payment for services), etc.

The current significant rules and conditions changes of medical services delivery require the public medical institutions to take decisive action in customer orientation to retain existing patients, attract new ones and remain competitive in the Ukrainian health care market.

In the frame of this study, the systematization of scientific background determined the basis of marketing policy in the public medical sector. Therefore, the core of the marketing relationship between health care providers and patients is rather satisfying patients' needs than providing and receiving medical services. Following the mentioned above, the marketing macroenvironment analysis involves studying economic, technological, political, demographic, natural and cultural impact factors. In this regard, an essential element of the marketing complex is the medical service as a set of measures to prevent diseases, diagnose and treat, and improve the patient's health.

Notably, the health care market is a segment of the world service market focused on international medical services exchange. In turn, the national health care market feature is combining private and public health care services, which minimize each other gaps.

The findings on impact analysis of the clinic's competitive forces showed that consumers, potential competitors, and suppliers had the most significant influence on the clinic competitiveness.

This study provides recommendations to improve the marketing activities of the medical institution. Thus, it is essential to focus efforts on the VIP patient's maintenance and take measures to retain specialists by offering better working conditions. Besides, the development of internal marketing requires implementing the best world practice focused on the consumer and the clinic's staff. Herewith, state medical institutions should take decisive customer-oriented actions to remain competitive in the change conditions in the Ukrainian health care market.

Author Contributions: conceptualization, Yu. Yu., O. P.; methodology, Yu. Yu., O. P.; validation, Yu. Yu., O. P.; formal analysis, Yu. Yu., O. P.; investigation, Yu. Yu., O. P. and M. P.; resources, O. P.; data curation, O.P., M. P.; writing - original draft preparation, Yu. Yu.; writing - review and editing, Yu. Yu.; supervision, Yu. Yu., O. P.

Funding: This research received no external funding.

\section{References}

Censor. (2020). The volume of the private medicine market. Retrieved from [Link] [Link]

Chornorotov, O. (2010). Characteristics of the private medicine market of Ukraine. Agency «Credit rating». Retrieved from 
Foygt, N. (2011). The evaluation of priorities in Primary Care reformation in Ukraine in the context of population aging. Derzhavne upravlinnya: udoskonalennya ta rozvytok, (8).

Kalinichenko, O. (2016). Instruments of marketing research in a health protection. Proceedings of the International and Practical Conference «Actual problems of youth in modern socio-economic conditions». 61.

Laburtseva, O. (2007). Research of the historical genesis of the modern concept of marketing. Marketing in Ukraine, (6), 57-

Legan, I., \& Krykun, O. (2020). Private medicine market of ukraine: features of regulation and directions of development. Galician economik journal, 3(64), 192-197.

Lekhan, V., Slabkyi, G., \& Shevchenko, M. (2010). Health care system strategy development: Ukrainian measuring. Ukraine. Nation's Health, 1(13), 5-23. [Google Scholar]

Levina, M. (2016). Theoretical marketing foundations. Bulletin of Kyiv National University. Taras Shevchenko. Ser.

Economics, 5, 70-75.

Medosvita (2020). The market of medical services in Ukraine. Retrieved from [Link]

Melnychenko, O. (2018). Modern aspects of public change management in the health care system of Ukraine. Proceedings of the International and Practical Conference «Marketing and management in the focus of the challenges of the new economy». 102106.

Polienko, M. (2005). Institutional aspects of improving the efficiency of public administration. Doctoral dissertation.

Popova, Yu. (2011). The essence and technical tools of Internet marketing. Retrieved from [Link]

Porter, M. (2015). Competition: a textbook. Kyiv: ed. Williams House, 495 p.

Shomnikova, A. (2009). Medical services market: problems of effective use of marketing research. RFI Scientific papers, (2) 131-136.

Shynkaryova, I. (2007). Quality of primary health care: assessment by patients. Bulletin of problems biology and medicine, 4 , 181-189.

Social communications research center (2020). Primary care reform: a new model for purchasing local health services. Retrieved from [Link]

Sokolova, Yu. \& Pasichnyk, K. (2019). Improvement of activity of state medical institution on the basis of marketing.

Economics and management of the national economy, 37, 150-158.

Vezha. (2020). Analysis of the medical services market in Ukraine. Retrieved from [Link

Yanchak, Ya. (2017). Effective development and functioning of the market of medical services in the conditions of globalization and integration processes in health. Journal of Lviv Polytechnic National University. Series of Science of Law, 876 (15).

Zatsna, L., \& Ivashkiv, T. (2017). Marketing of medical services and features of medical institutions market development in the conditions of economic transformation. Crimean economy, 1(42), 363-367.

Zukin, V. (2017). Ukrainian market of private medicine: realities and prospects. Private doctor, 12-15.

Ю. С. Юла, Сумський державний університет (Україна);

О. М. Пушко, Сумський державний університет (Україна);

М. Палієнко, Університет Інсубрії (Італія).

Рекомендації щодо удосконалення маркетингової політики поліклініки

У статті розглядаються питання вдосконалення маркетингової політики поліклініки. Систематизація літературних джерел та підходів до розв'язання проблеми удосконалення маркетингової політики поліклініки свідчить про значну роль маркетингу та необхідність його активного застосування практично в усіх галузях і сферах діяльності, зокрема в галузі охорони здоров'я. Актуальність розв'язання наукової проблеми полягає в необхідності просування медичних послуг, де маркетингова діяльність сприяє налагодженню відносин між постачальниками та споживачами медичних послуг. Автори відмітили, що пацієнти мають низький рівень поінфформованості у медичних послугах, що ускладнює розуміння ринку медичних послуг. У свою чергу, заклади медичних послуг державного та комунального типів мають пасивну маркетингову політику, яка є неконкурентоспроможною порівняно з приватними медичними закладами. Медичні заклади державного та комунального типу у більшості випадків не застосовують маркетингові інструменти для ознайомлення споживача з переліком доступних послуг, не інформують споживачів про розширення медичних послуг та переваги закладу. Об'єктом дослідження обрано управління в галузі охорони здоров'я. За результатами емпіричного аналізу шляхів удосконалення маркетингової політики поліклініки встановлено, що реформування медичної галузі України посилює процеси конкуренції на ринку. Таким чином, перед державними медичними установами постала необхідність боротися (зокрема з приватними медичними закладами) за споживача та державне фінансування пакету базових медичних послуг. Дослідження емпірично підтверджує та теоретично доводить, наявність конкуренції між приватними та державними медичними закладами на ринку медичних послуг. Результати проведеного дослідження можуть бути корисними для удосконалення маркетингової політики поліклінік державного та комунального типів, зокрема, щодо пошуку ефективних інструментів маркетингового просування медичних послуг серед цільової аудиторії різного віку та соціально-економічного статусу.

Ключові слова: маркетингова політика, маркетингові інструменти, охорона здоров'я, персонал, цінова політика.

Manuscript received: 12.10 .2020

(c) The author(s) 2020. This article is published with open access at Sumy State University. 